\title{
Evaluation of quality and storability of "Sewy" date palm cv. in different Production areas in Egypt
}

\author{
Tarek M. El-Kafrawy ${ }^{1}$, Ghazzawy H.S. ${ }^{1,2}$, Nahed Ahmed ${ }^{3}$ and Dalia M. Hikal ${ }^{4}$ \\ ${ }^{1}$ Central Laboratory for Date palm Research and Development, Agriculture Research Center, Giza, Egypt. \\ ${ }^{2}$ Date palm Research Center of Excellence, King Faisal University, Saudi Arabia. \\ ${ }^{3}$ Hortculture Research Institute, Pomology, Fruit Handling Res. Division, Agriculture Research center, Giza, Egypt. \\ ${ }^{4}$ Nutrition and Food Science, Home Economics Department, Faculty of Specific Education, Mansoura University, Egypt.
}

Received date: 24 January 2018, Accepted date: 08 March 2018, Online date: 26 March 2018

\author{
Address for Correspondence: \\ Hesham Ghazzawy \\ Central Laboratory for Date palm Research and Development, Agriculture Research Center, Giza, Egypt. \\ e-mail: hishamdates@hotmail.com
}

Copyright $\odot 2018$ by authors and American-Eurasian Network for Scientific Information.

This work is licensed under the Creative Commons Attribution International License (CC BY).

http://creativecommons.org/licenses/by/4.0/

\section{(i) Open Access}

\begin{abstract}
This study was carried out during two successive seasons on semi dry date palm fruits "Sewy" cv. which cultivated in different production areas located in Arab Republic of Egypt like New Valley, El-Wahat Bahria and Oasis of Siwa in order to evaluate fruit quality properties through some sensory properties such as taste, shape and degree of Tamr stag \& homogeneity of ripening and physical properties i.e. weight fruit, fruit length and diameter, shape of the fruit, the weight of the seed and flesh weight $\%$, seed weight $\%$, the thickness flesh and dry weight $(\mathrm{g})$, Humidity(g) and Humidity $(\%)$ and the chemical properties such as total soluble solids $\%$, total acidity $\%$, Tannins $\%$ and as well as evaluate the behavior of the fruits during cold storage of all studied area by determined physical properties i.e. decay\%, weight loss\%, fruit texture and chemical properties such as a total soluble solids (T.S.S\%), total acidity and the percentage of tannins through the various storage period which lasted 420 days where the storage temperature $5^{\circ} \mathrm{c} \pm 2$ with a humidity of $85 \%$ for different periods and executed the experiment due to poor cold storability of the fruits of El-Wahat Bahria area for the emergence of sugary spots on the fruit which reduces the quality of marketing. The study showed that there is a clear difference in the quality of through physical properties, chemical, and storability traits under study, for the first experiment the quality attributes recorded for El-Wahat Bahria increased of fruit weight, flesh weight, fruit length and dimension, flesh thickness and flesh weight\% While, the fruits of the New Valley location recorded the lowest seed $\%$ and the highest fruit shape, fruit texture, total soluble solids (T.S.S\%) and lower in acidity \% Siwa area recorded lower seed weight and the percentage of tannin. Date of Second experiment showed that New Valley is best areas for good storability of list where recorded the lowest decay\%, weight loss \% and the highest fruit texture and T.S.S\%. Also, it characterized by good taste, good appearance and color of the fruits of the accepted.

KEY WORDS

Storability, Quality, T.S.S, Sewy, Taste.
\end{abstract}

\section{INTRODUCTION}

Date palm (Phoenix dactylifera L.) is a great significance fruit and considered one of the majority of fruit crops in Egypt. The date palm fruits are highly requested and utilized everywhere the Arab countries, particularly in the Middle East [1]. The total world production was 7.549 million ton, which equal 3.90 million dollar in 2012. Arab production of dates about $72 \%$ of global production and however, the nearly $50 \%$ of the productivity that is exported. Production of Egypt ranked in First Arab countries (19.5\%) for 2012, followed by 
Tarek M. El-Kafrawy et al., 2018. Evaluation of quality and storability of "Sewy" date palm cv. in different Production areas in Egypt. American-Eurasian Journal of Sustainable Agriculture. 12(1): 30-39. DOI: 10.22587/aejsa.2018.12.1.5

Iran (14.1\%) and Saudi Arabia (13.9\%) and Algeria (8.7\%) and Pakistan (7.9\%) [2,3]. In Egypt about 12.83 million bearing female palms according to the latest census [4], which are distributed among different governorates. Our production in Egypt, from the different kinds of date exceeds (1.465.030) tons, favoured by local and foreign consumers, it increased Egypt's exports of dates over the past five years as she was $0.6 \%$ and had reached $1.15 \%$ of the amount of annual output by 13.22 thousand tons per year by 17.2 million dollars a year and this development to catch evolution incident in countries exporting dates and nations compete in this area and not commensurate with an annual production volume to Egypt [5].

Date palm varieties were categories according to the obtainable heat units into a soft, semi-dry and dry. In general, in the Oases the semi-dry cultivars are the most prominent. Heat units were studied in connection to $18^{\circ} \mathrm{c}$ or above [6] through the period from May to the end of October but the last is additional true and accepted by most researchers $[7,8]$. The same authors' usually specified various varieties of date palm vary in their showing and these variations are decided by general, cultural and environmental agents may be caused the differences in the achievement of various varieties, the suitability of these varieties from the consumers' point of opinion is predominantly estimated from various points. Research of growth, yield and homologically leading external and internal, properties of fruit in date palm varieties are considered of the significant criteria for the estimate of varieties. Egyptian date palm cultivars classified into three types based on the fruit moisture content namely: dry dates "Tamr" Semi- dry dates "Aqua" and soft dates "Rutab" as reported by [9,10]. Improving the date harvesting, handling, marketing, packaging, storage, transporting and exporting to foreign markets are all an important roads to expand our exports and enrich our income harvesting, processing and marketing, deficiency of inhabitant certified and trained staff and labor, and inadequate investigate and being developed. To overcome these challenges, environmental parties are encouraged by organic cultivation as an environmentally-friendly process and are criticizing conventional production. There is a growing discussion that had continued date palm growers who are changing their groves to 'organic' [11]. In this paper, we will compare 'conventional' and 'organic' cultivation of date palm, it's processing, marketing, and pest control. [12] studied physical properties of date palm (cv. Samaran) at storage duration is necessary to develop optimal process technology of storage material.

The significance and broad culture regions of conventional date palm cultivation, field, and postharvest losses are high, and methods for measuring product quality and utilize of date products and by-products necessity being improved. Great constraints contain low-quality palm varieties, poor farm administration. Finally, the post-harvest and processing to improve the qualities of the quality and packaging of the important things for marketing and final Altsidiromahsalh to production processes and Agriculture Date Palm, especially within the same product transactions and this we dealt with in this research assess the final product of the harvest dates Semi-dry cultivar "Sewy" between different areas of production in terms of quality attributes (properties physical and chemical) and the extent of its storeability to as well as in the different production areas.

The main objective of this work was evaluate the quality of the fruits of palm produaction, storage and the possibility of benefiting from this study and export marketing Sewy cv. in three different areas of a grown: New Valley, El-Wahat Bahria and Siwa.

\section{MATERIALS AND METHODS}

This study was conducted during two sucssive seasons "Sewy" dates (semi-dry cultivar) to evaluate aspects of convergence and divergence in the class in terms of quality attributes grown in different regions as storability on fruit quality during cold storage. The collected fruits were harvested at ripening (Tamr stage) from three different areas under study (New Valley, El-Wahat and Siwa Oasis) [Fig. 1] in phase with the dates of the best three date processing factories each region after conducting manufacturing, drying, sorting, packing the various transactions, used and the packaging in each area under study randomly. The selected palms trees of Sewy cultivar were in good physical condition. Bunches were pollinated from the same male palm tree free diseases and free from insect damage. Also, were subjected to the same horticultural management treatments. Fruits packed into a plastic basket and were divided into three groups:

Group A: Fruits selected randomly from New Vally.

Group B: Fruits selected randomly from El-Wahat Bahria.

Group C: Fruits selected randomly from Oasis of Siwa.

Two experimental were done as follow:

- The first Experiment: Evaluation of quality of "Sewy" dates in three different production areas (New Valley, El-Wahat and Siwa Oasis).

The Second Experiment: Evaluation of storability of "Sewy" dates in different production areas.

The fruits packed in six boxes, representing three replicates, were used to notation the weight loss, decay Percentage, deduction of physical and chemical constituents before and during storage for each of the 
Tarek M. El-Kafrawy et al., 2018. Evaluation of quality and storability of "Sewy" date palm cv. in different Production areas in Egypt. American-Eurasian Journal of Sustainable Agriculture. 12(1): 30-39. DOI: 10.22587/aejsa.2018.12.1.5

study areas. At each harvest date, the samples of fruits from the experimented treatments were kept at $85 \%$ relative humidity (R.H) and $5 \pm 2^{\circ} \mathrm{C}$ for (420) days. Every (60) days during cold storage,physical and chemical properties of the fruits were determined, as follow:

$-\mathbf{B}_{1}$ : Control treatment (0) days.

-B $\mathbf{B}_{2}$ : Samples were kept at $5 \pm 2^{\circ} \mathrm{C}$ and $85 \%$ relative humidity (R.H) for 60 days.

$-B_{3}$ : Samples were kept at $5 \pm 2^{\circ} \mathrm{C}$ and $85 \%$ relative humidity (R.H) for 120 days.

$-\mathbf{B}_{4}$ : Samples were kept at $5 \pm 2^{\circ} \mathrm{C}$ and $85 \%$ relative humidity (R.H) for 180 days.

-B B $_{5}$ Samples were kept at $5 \pm 2^{\circ} \mathrm{C}$ and $85 \%$ relative humidity (R.H) for 240 days.

$-\mathbf{B}_{6}$ : Samples were kept at $5 \pm 2^{\circ} \mathrm{C}$ and $85 \%$ relative humidity (R.H) for 300 days.

$-B_{7}$ : Samples were kept at $5 \pm 2^{\circ} \mathrm{C}$ and $85 \%$ relative humidity (R.H) for 360 days.

$-B_{8}$ : Samples were kept at $5 \pm 2^{\circ} \mathrm{C}$ and $85 \%$ relative humidity (R.H) for 420 days.

\section{Each group was divided into two sections: a) Physical properties:}

After and before different treatments, three replicate Consist of fruits sampleswere taken from each for the determination of:

Fruit weight (g), Fresh weight (g), Flesh weight (g \& \%), Dry weight (g), Humidity (g \& \%), Seed weight ( $\mathrm{g} \&$ $\%)$. Fruit dimension: Fruit length "L" $(\mathrm{cm})$ and Fruit diameter "D" (cm), Fruit shape (L:D ratio), Thickness $(\mathrm{mm} \& \%)$ and External color.

\section{Study storage qualities:}

a) Physical properties during cold storage such as decay by the discarded fruits included all the spoiled or injured fruits resulting from fungus or bacteria, shriveling and other various defects, were calculated and expressed as decay (\%)- loss in fruit weight $(\%)$ of loss in fruit weight was calculated - Fruit texture $\left(\mathrm{g} / \mathrm{cm}^{2}\right)$.

b) Chemical properties: before and during cold storage different treatments, three replicate Consist of (50) fruits were taken from each for the determination of:

(T.S.S) \%: (Total soluble solids) was assessed by using the Abbe digital refractometer according to [13]. Titratable acidity \%: was measured by titration against $0.1 \mathrm{~N}$. Sodium hydroxide using phenolphthalein as an indicator [13].

- Tannins content: was determined (as gm gallotanninc acid / 100gm dry weight) according to the method of [14].

Statistical analysis:

The statistical analysis of the present data was carried out according to [15]. Means of the obtained results at different treatments were compared using L.S.D. test, at 0.05 level.

\section{RESULTS AND DISCUSSION}

A- The first Experiment:

Evaluation of quality of "Sewy" dates in different production areas.

1- Physical properties of dates:

Date tabulated in Table (1) show the effect of different location on fruit Physical properties, Average fruit weight and average flesh weight of "Sewy" dates during 2014 and 2015 seasons. It is clear the location ElWahat after that New Valley reduced dates compared with Siwa dates. However, the fruit weight in the ElWahat $(12.41 \mathrm{~g})$ and flesh weight $(10.84 \mathrm{~g})$ in the first season and $(11.77 \mathrm{~g}),(10.17 \mathrm{~g})$ attributed in the second season compared with Siwa dates. It could be $(8.41 \mathrm{~g}),(7.13 \mathrm{~g})$ in the first season but the second season clear that $(7.75 \mathrm{~g}),(6.50 \mathrm{~g})$ attributed for "Sewy" dates. Generally, we find that there is a significant difference between the two is clear from the three production areas of the dates under study. Average fruit weight and flesh weight trend was differing, where all location treatments increased fruit weight and flesh weight on El-Wahat than the Siwa dates. On the other hand, show the Seed weight (g) in the Table (1), it could be concluded that seed weight gradually increased with advanced fruit age. However, significant differences were detected between El-Wahat area but no significant different location between that New Valley and Siwa area. Generally, Seed weight (g) ElWahat dates recorded the highest rate $(1.57 \mathrm{~g})$ and $(1.60 \mathrm{~g})$, while both of equal New Valley $(1.34 \mathrm{~g}),(1.38 \mathrm{~g})$ and Siwa (1.28g) and (1.25g) for two seasons on the Straight. On another hand increased the seed \% of Siwa area compared with New Valley and El-Wahat, where both of them recorded that $(15.23 \%),(16.25 \%),(13.58 \%)$, $(14.11 \%),(12.66 \%)$ and $(13.58 \%)$ for two seasons on the Straight. Generally, significant differences were detected between Siwa area but no significant different location between that New Valley and El-Wahat area for two seasons on the Straight. Show the average fruit diameter $(\mathrm{cm})$ and fruit length $(\mathrm{cm})$ slightly affected with location treatments and consequently fruit shape (L:D ratio) slightly changed. 
Tarek M. El-Kafrawy et al., 2018. Evaluation of quality and storability of "Sewy" date palm cv. in different Production areas in Egypt. American-Eurasian Journal of Sustainable Agriculture. 12(1): 30-39. DOI: 10.22587/aejsa.2018.12.1.5

However, It is clear that fruit diameter was increased with El-Wahat dates area $(2.70 \mathrm{~cm}),(2.43 \mathrm{~cm})$ for two seasons and after that New Valley recorded that $(2.27 \mathrm{~cm})$ and $(2.20 \mathrm{~cm})$ reduced dates compared with Siwa dates $(2.00 \mathrm{~cm})$ and $(2.00 \mathrm{~cm})$ for two seasons on the Straight. Generally, significant differences were detected between different dates area. On the other hand, it is clear that fruit length. We find that it is moving in the same direction was increased with El-Wahat dates area $(4.50 \mathrm{~cm})$ and $(3.93 \mathrm{~cm})$ for two seasons and after that New Valley recorded that $(3.93 \mathrm{~cm})$ and $(3.67 \mathrm{~cm})$ reduced dates compared with Siwa dates $(3.20 \mathrm{~cm})$ and $(3.00 \mathrm{~cm})$. For two seasons on the Straight. Generally, significant differences were detected between different dates area.

Regarding "Sewy" fruit shape (length and diameter), it could be noticed that was increased with New Valley recorded that (1.74) and (1.67) after that El-Wahat dates recorded that (1.67) and (1.62) compared with Siwa dates (1.60) and (1.50). For two seasons on the Straight. It was significant differences were detected between different dates area. Flesh \% of "Sewy" dates slightly affected with different location, where it was ranged from (84.77 to $87.34 \%$ in the first season) and from (83.75 to $86.42 \%$ in the second season). There are significant differences between both El-Wahat dates and New Valley recorded that $(87.34 \%)$ and $(86.42 \%)$ after that recorded that $(86.42 \%)$ and $(85.88 \%)$ compared with Siwa dates $(84.77 \%)$ and $(83.75 \%)$. For two seasons on the Straight. On the other hand, Flesh thickness $(\mathrm{mm})$, it is clear that Flesh thickness. We find that it was increased with El-Wahat dates area $(61.33 \mathrm{~mm})$ and $(56.00 \mathrm{~mm})$ for two seasons and after that New Valley recorded that $(51.00 \mathrm{~mm})$ and $(47.00 \mathrm{~mm})$ reduced dates compared with Siwa dates $(40.00 \mathrm{~mm})$ and $(41.67 \mathrm{~mm})$ for two seasons on the Straight. Generally, significant differences were detected between different dates area.

Show the average fruit texture $\left(\mathrm{g} / \mathrm{cm}^{2}\right)$ slightly affected with location treatments, where it was ranged from ( 92.00 to $66.33 \mathrm{~mm}$ in the first season) and from (74.67 to $72.33 \mathrm{~mm}$ in the second season). The first one New Valley it recorded that $(92.00 \mathrm{~mm})$ and $(74.67 \mathrm{~mm})$ after that Siwa dates the last one El-Wahat dates area it recorded that $(66.33 \mathrm{~mm})$ and $(74.00 \mathrm{~mm})$. Generally, significant differences were detected between different dates area.

Table (1): Effect of location on fruit physical properties of "Sewy" dates during two successive seasons.

\begin{tabular}{|c|c|c|c|c|c|c|c|c|c|c|}
\hline \multicolumn{11}{|c|}{$1^{\text {st }}$ Season } \\
\hline & $\begin{array}{c}\text { Fruit } \\
\text { weight } \\
(\mathrm{g})\end{array}$ & $\begin{array}{l}\text { Flesh } \\
\text { weight } \\
(\mathrm{g})\end{array}$ & $\begin{array}{l}\text { Flesh } \\
(\%)\end{array}$ & $\begin{array}{c}\text { Seed } \\
\text { weight }(\mathrm{g})\end{array}$ & $\begin{array}{l}\text { Seed } \\
(\%)\end{array}$ & $\begin{array}{c}\text { Flesh } \\
\text { thickness } \\
(\mathrm{mm})\end{array}$ & $\begin{array}{l}\text { Fruit } \\
\text { length } \\
(\mathrm{cm})\end{array}$ & $\begin{array}{c}\text { Fruit } \\
\text { diameter } \\
(\mathrm{cm})\end{array}$ & $\begin{array}{l}\text { Fruit } \\
\text { shape } \\
(\mathrm{L} / \mathrm{D})\end{array}$ & $\begin{array}{l}\text { Fruit } \\
\text { texture } \\
\left(\mathrm{g} / \mathrm{cm}^{2}\right)\end{array}$ \\
\hline $\mathrm{A}_{1}$ & 9.86 & 8.52 & 86.42 & 1.34 & 13.58 & 51.00 & 3.93 & 2.27 & 1.74 & 92.00 \\
\hline $\mathrm{A}_{2}$ & 12.41 & 10.84 & 87.34 & 1.57 & 12.66 & 61.33 & 4.50 & 2.70 & 1.67 & 66.33 \\
\hline $\mathrm{A}_{3}$ & 8.41 & 7.13 & 84.77 & 1.28 & 15.23 & 40.00 & 3.20 & 2.00 & 1.60 & 80.33 \\
\hline L.S.D. & 0.64 & 0.62 & 1.09 & 0.11 & 1.08 & 4.55 & 0.18 & 0.15 & 0.09 & 4.45 \\
\hline \multicolumn{11}{|c|}{$2^{\text {nd }}$ Season } \\
\hline & $\begin{array}{c}\text { Fruit } \\
\text { weight } \\
(\mathrm{g})\end{array}$ & $\begin{array}{c}\text { Flesh } \\
\text { weight } \\
(\mathrm{g})\end{array}$ & $\begin{array}{l}\text { Flesh } \\
(\%)\end{array}$ & $\begin{array}{c}\text { Seed } \\
\text { weight }(\mathrm{g})\end{array}$ & $\begin{array}{l}\text { Seed } \\
(\%)\end{array}$ & $\begin{array}{c}\text { Flesh } \\
\text { thickness } \\
(\mathrm{mm})\end{array}$ & $\begin{array}{l}\text { Fruit } \\
\text { length } \\
(\mathrm{cm})\end{array}$ & $\begin{array}{c}\text { Fruit } \\
\text { diameter } \\
(\mathrm{cm})\end{array}$ & $\begin{array}{l}\text { Fruit } \\
\text { shape } \\
(\mathrm{L} / \mathrm{D})\end{array}$ & $\begin{array}{c}\text { Fruit } \\
\text { texture } \\
\left(\mathrm{g} / \mathrm{cm}^{2}\right)\end{array}$ \\
\hline $\mathrm{A}_{1}$ & 9.99 & 8.61 & 85.88 & 1.38 & 14.11 & 47.00 & 3.67 & 2.20 & 1.67 & 74.67 \\
\hline $\mathrm{A}_{2}$ & 11.77 & 10.17 & 86.42 & 1.60 & 13.58 & 56.00 & 3.93 & 2.43 & 1.62 & 74.00 \\
\hline $\mathrm{A}_{3}$ & 7.75 & 6.50 & 83.75 & 1.25 & 16.25 & 41.67 & 3.00 & 2.00 & 1.50 & 72.33 \\
\hline L.S.D. & 0.76 & 0.71 & 1.78 & 0.17 & 1.78 & 4.42 & 0.23 & 0.19 & 0.04 & 3.68 \\
\hline
\end{tabular}

2- Effect of location on fruit humidity of "Sewy" dates during two successive seasons:

The study showed through the Table (2) the effect of Fruit humidity percentage of "Sewy" dates to analyze moisture content in the fruit during the seasons of the study. Significant differences were obtained among the humidity percentage of deferent location dates, said the fruits of the El-Wahat area higher proportion of moisture in the fruit compared with the dates of the New Valley area, as recorded the lowest percentage of moisture in the fruits of that area. This may be due the high proportion of losses and in storability to the reason for the high percentage of moisture off.

3- Organoleptic evaluation of "Sewy" dates:

As in all foods, the organoleptic taste is generally the final guide of the quality from the consumers point of view [20] Thus, it is beneficial to make a comparison between all treatments. Mean value of sensory scores namely color, taste, General Appearance, and Homogeneity of ripening of prepared treatments are shown in Table (3). Significant differences were obtained among the taste samples. Analysis of variance showed that the New Valley dates area are good taste, good appearance and color fruits are accepted. But the location El-Wahat dates it is clear good Homogeneity of ripening for the two seasons under study. 
Tarek M. El-Kafrawy et al., 2018. Evaluation of quality and storability of "Sewy" date palm cv. in different Production areas in Egypt. American-Eurasian Journal of Sustainable Agriculture. 12(1): 30-39. DOI: 10.22587/aejsa.2018.12.1.5

Table (2): Effect of location on fruit humidity of "Sewy" dates during two successive seasons.

\begin{tabular}{|c|c|c|c|c|}
\hline \multicolumn{5}{|c|}{$1^{\text {st }}$ Season } \\
\hline & $\begin{array}{l}\text { Fresh weight } \\
\text { (g) }\end{array}$ & $\begin{array}{l}\text { Dry weight } \\
\text { (g) }\end{array}$ & $\begin{array}{l}\text { Humidity } \\
\text { (g) }\end{array}$ & $\begin{array}{c}\text { Humidity } \\
(\%)\end{array}$ \\
\hline $\mathrm{A}_{1}$ & 13.27 & 11.70 & 4.73 & 11.87 \\
\hline $\mathrm{A}_{2}$ & 8.91 & 7.00 & 5.72 & 21.41 \\
\hline $\mathrm{A}_{3}$ & 12.25 & 10.27 & 5.92 & 16.21 \\
\hline L.S.D. & 2.57 & 2.13 & 1.35 & 0.99 \\
\hline \multicolumn{5}{|c|}{$2^{\text {nd }}$ Season } \\
\hline & $\begin{array}{l}\text { Fresh weight } \\
\text { (g) }\end{array}$ & $\begin{array}{l}\text { Dry weight } \\
\text { (g) }\end{array}$ & $\begin{array}{l}\text { Humidity } \\
\text { (g) }\end{array}$ & $\begin{array}{c}\text { Humidity } \\
(\%)\end{array}$ \\
\hline $\mathrm{A}_{1}$ & 12.37 & 9.81 & 4.39 & 11.80 \\
\hline $\mathrm{A}_{2}$ & 11.39 & 8.94 & 7.35 & 21.50 \\
\hline $\mathrm{A}_{3}$ & 11.65 & 9.93 & 5.17 & 14.78 \\
\hline L.S.D. & 0.87 & 1.50 & 0.57 & 0.77 \\
\hline
\end{tabular}

Table (3): Effect of location on Organoleptic of "Sewy" dates during two successive seasons.

\begin{tabular}{|c|c|c|c|c|}
\hline & \multicolumn{4}{|c|}{$1^{\text {st }}$ Season } \\
\hline & Taste & General Appearance & $\begin{array}{l}\text { Homogeneity of } \\
\text { Ripening }\end{array}$ & Color \\
\hline $\mathrm{A}_{1}$ & 9.44 & 9.06 & 7.56 & 9.28 \\
\hline $\mathrm{A}_{2}$ & 8.44 & 8.33 & 8.94 & 8.78 \\
\hline $\mathrm{A}_{3}$ & 7.61 & 7.67 & 8.61 & 7.67 \\
\hline \multirow[t]{3}{*}{ L.S.D. } & 0.30 & 0.23 & 0.17 & 0.30 \\
\hline & \multicolumn{4}{|c|}{$2^{\text {nd }}$ Season } \\
\hline & Taste & General Appearance & $\begin{array}{l}\text { Homogeneity of } \\
\text { ripening }\end{array}$ & Color \\
\hline $\mathrm{A}_{1}$ & 9.21 & 9.36 & 7.96 & 9.13 \\
\hline $\mathrm{A}_{2}$ & 8.63 & 8.71 & 9.21 & 8.66 \\
\hline $\mathrm{A}_{3}$ & 8.15 & 8.27 & 8.47 & 7.94 \\
\hline L.S.D. & 0.42 & 0.28 & 0.23 & 0.38 \\
\hline
\end{tabular}

B- The Second Experiment:-

Evaluation of storability of "Sewy" dates in different production areas.

A- Physical properties

Weight Loss\%:

Data tabulated in Table (4) show the effect of location treatments and storability as it is mostly greater with development cold storage periods with all location treatments. After 420 days of cold storage weight loss $\%$ ranged to 3.09, 3.77 and 4.78 for New Valley dates, Siwa dates and last one El-Wahat dates area., respectively 
Tarek M. El-Kafrawy et al., 2018. Evaluation of quality and storability of "Sewy" date palm cv. in different Production areas in Egypt. American-Eurasian Journal of Sustainable Agriculture. 12(1): 30-39. DOI: 10.22587/aejsa.2018.12.1.5

(data of first season). However, New Valley dates, "Sewy" dates exhibited the least values of weight loss followed by Siwa dates whereas El-Wahat dates registered the elevated values of weight loss with considerable variations among them, it is clear that New Valley dates "Sewy" fruits were superior than Siwa dates and after that El-Wahat dates fruits and stored well for 420 days without losses in fruit goodness. The same trend of findings was also noted in the second season of the study.

Table (4): Some physical properties of "Sewy" dates for deferent location produced on cold stored, during two successive seasons.

\begin{tabular}{|c|c|c|c|c|c|c|c|c|}
\hline & & & \multicolumn{2}{|c|}{$\begin{array}{l}\text { Weight loss } \\
(\%)\end{array}$} & \multicolumn{2}{|c|}{$\begin{array}{c}\text { Decay } \\
(\%)\end{array}$} & \multicolumn{2}{|c|}{$\begin{array}{l}\text { Fruit texture } \\
\quad\left(\mathrm{g} / \mathrm{cm}^{2}\right)\end{array}$} \\
\hline & & & $\begin{array}{c}1^{\text {st }} \\
\text { season }\end{array}$ & $\begin{array}{c}2^{\text {nd }} \\
\text { season }\end{array}$ & $\begin{array}{c}1^{\text {st }} \\
\text { season }\end{array}$ & $\begin{array}{c}2^{\text {nd }} \\
\text { season }\end{array}$ & $\begin{array}{c}1^{\text {st }} \\
\text { season }\end{array}$ & $\begin{array}{c}2^{\text {nd }} \\
\text { season }\end{array}$ \\
\hline \multirow{3}{*}{ (A) : Location } & \multirow{3}{*}{\multicolumn{2}{|c|}{$\begin{array}{l}\left(A_{1}\right) \text { New Valley } \\
\text { (A2) El-Wahat } \\
\text { (A3) Siwa }\end{array}$}} & 1.80 & 2.06 & 13.54 & 9.13 & 82.96 & 76.21 \\
\hline & & & 2.68 & 2.17 & 28.67 & 9.25 & 58.00 & 64.88 \\
\hline & & & 2.12 & 2.28 & 19.67 & 9.92 & 71.54 & 65.33 \\
\hline \multicolumn{3}{|c|}{ L.S.D. (A) = } & 0.08 & 0.16 & 1.79 & 2.62 & 1.57 & 1.30 \\
\hline \multirow{8}{*}{$\begin{array}{l}\text { (B) : Storage } \\
\text { Date }\end{array}$} & \multicolumn{2}{|c|}{$\left(\mathrm{B}_{1}\right) 0$ day } & 0.54 & 0.66 & 0.00 & 0.00 & 79.56 & 73.67 \\
\hline & \multicolumn{2}{|c|}{$\left(\mathrm{B}_{2}\right) 60$ days } & 0.96 & 1.04 & 0.00 & 0.00 & 78.11 & 71.44 \\
\hline & \multicolumn{2}{|c|}{$\left(\mathrm{B}_{3}\right) 120$ days } & 1.49 & 1.56 & 3.33 & 0.00 & 75.89 & 69.22 \\
\hline & \multicolumn{2}{|c|}{$\left(\mathrm{B}_{4}\right) 180$ days } & 1.88 & 2.01 & 16.00 & 3.00 & 73.22 & 67.33 \\
\hline & \multicolumn{2}{|c|}{$\left(B_{5}\right) 240$ days } & 2.52 & 2.38 & 23.78 & 9.67 & 70.00 & 65.33 \\
\hline & \multicolumn{2}{|c|}{$\left(\mathrm{B}_{6}\right) 300$ days } & 2.99 & 2.79 & 31.89 & 14.89 & 66.89 & 62.78 \\
\hline & \multicolumn{2}{|c|}{$\left(\mathrm{B}_{7}\right) 360$ days } & 3.34 & 3.15 & 40.67 & 18.78 & 63.22 & 59.67 \\
\hline & \multicolumn{2}{|c|}{$\left(\mathrm{B}_{8}\right) 420$ days } & 3.88 & 3.74 & 49.33 & 29.11 & 59.78 & 57.00 \\
\hline \multicolumn{3}{|c|}{ L.S.D. $(\mathrm{B})=$} & 0.13 & 0.26 & 2.92 & 4.28 & 2.57 & 2.12 \\
\hline & \multirow[t]{8}{*}{$\mathrm{A}_{1}$} & $\mathrm{~B}_{1}$ & 0.33 & 0.53 & 0.00 & 0.00 & 92.00 & 74.67 \\
\hline & & $\mathrm{B}_{2}$ & 0.69 & 1.07 & 0.00 & 0.00 & 90.33 & 72.33 \\
\hline$(\mathrm{AXB})$ & & $\mathrm{B}_{3}$ & 1.21 & 1.37 & 0.00 & 0.00 & 88.33 & 70.67 \\
\hline Interaction & & $\mathrm{B}_{4}$ & 1.49 & 1.92 & 9.33 & 2.00 & 85.67 & 68.00 \\
\hline & & $\mathrm{B}_{5}$ & 2.22 & 2.29 & 14.33 & 9.33 & 82.00 & 66.33 \\
\hline & & $\mathrm{B}_{6}$ & 2.54 & 2.73 & 21.33 & 15.33 & 78.67 & 64.67 \\
\hline & & $\mathrm{B}_{7}$ & 2.85 & 3.04 & 28.33 & 18.67 & 75.00 & 61.67 \\
\hline & & $\mathrm{B}_{8}$ & 3.09 & 3.50 & 35.00 & 27.67 & 71.67 & 59.33 \\
\hline & \multirow[t]{8}{*}{$\mathrm{A}_{2}$} & $\mathrm{~B}_{1}$ & 0.81 & 0.68 & 0.00 & 0.00 & 66.33 & 74.00 \\
\hline & & $\mathrm{B}_{2}$ & 1.31 & 1.03 & 0.00 & 0.00 & 65.33 & 70.67 \\
\hline & & $\mathrm{B}_{3}$ & 1.77 & 1.56 & 9.00 & 0.00 & 63.00 & 68.67 \\
\hline & & $\mathrm{B}_{4}$ & 2.31 & 2.07 & 24.67 & 3.00 & 60.00 & 67.33 \\
\hline & & $\mathrm{B}_{5}$ & 2.97 & 2.43 & 33.67 & 9.00 & 57.00 & 65.00 \\
\hline & & $\mathrm{B}_{6}$ & 3.55 & 2.73 & 45.33 & 14.67 & 54.33 & 62.00 \\
\hline & & $\mathrm{B}_{7}$ & 3.95 & 3.06 & 53.67 & 18.00 & 50.67 & 58.67 \\
\hline & & $\mathrm{B}_{8}$ & 4.78 & 3.77 & 63.00 & 29.33 & 47.33 & 56.33 \\
\hline & \multirow[t]{8}{*}{$\mathrm{A}_{3}$} & $\mathrm{~B}_{1}$ & 0.50 & 0.77 & 0.00 & 0.00 & 80.33 & 72.33 \\
\hline & & $\mathrm{B}_{2}$ & 0.90 & 1.03 & 0.00 & 0.00 & 78.67 & 71.33 \\
\hline & & $\mathrm{B}_{3}$ & 1.50 & 1.74 & 1.00 & 0.00 & 76.33 & 68.33 \\
\hline & & $\mathrm{B}_{4}$ & 1.85 & 2.05 & 14.00 & 4.00 & 74.00 & 66.67 \\
\hline & & $\mathrm{B}_{5}$ & 2.38 & 2.42 & 23.33 & 10.67 & 71.00 & 64.67 \\
\hline & & $\mathrm{B}_{6}$ & 2.87 & 2.92 & 29.00 & 14.67 & 67.67 & 61.67 \\
\hline & & $\mathrm{B}_{7}$ & 3.21 & 3.37 & 40.00 & 19.67 & 64.00 & 58.67 \\
\hline & & $\mathrm{B}_{8}$ & 3.77 & 3.93 & 50.00 & 30.33 & 60.33 & 55.33 \\
\hline \multicolumn{3}{|c|}{ L.S.D. $(\mathrm{AXB})=$} & 0.22 & 0.44 & 5.05 & 7.41 & 4.45 & 3.68 \\
\hline
\end{tabular}

Fruit Decay\%:

Data in Table (4) showed that the influence of various location and storability on fruit decay\% which increased with development in cold storage periods regardless of the utilize therapy. No fruit decay\% was showed till 120 and 180 days in the first and second seasons, respectively. Meanwhile, New Valley dates exhibited the minimum worth of fruit decay through all cold storage periods followed by Siwa dates whereas the 
Tarek M. El-Kafrawy et al., 2018. Evaluation of quality and storability of "Sewy" date palm cv. in different Production areas in Egypt. American-Eurasian Journal of Sustainable Agriculture. 12(1): 30-39. DOI: 10.22587/aejsa.2018.12.1.5

El-Wahat date's region exhibited the highest fruit decay\%. Usually, it could be noticed that the three locations produced stored fruits for 420days without reaching 50.00\% average decay except El-Wahat date's area. After 420 days of cold storage, New Valley dates recorded $35.00 \%$ decay against $50.00 \%$ for Siwa dates and $63.00 \%$ for El-Wahat date's area at the first season. The lowest of fruit decay was showed with New Valley dates than other therapy as being caused to the prevention of enzyme activity and decreased fruit decay. From the results, it could be awarded that "Sewy" New Valley dates could be stored for 240 days with minimal fruit decay than $10 \%$ than with the El-Wahat dates area recorded that $24.67 \%$. The same trend of findings was also attended in the second season.

Fruit Texture $\left(\mathrm{g} / \mathrm{cm}^{2}\right)$ :

Data in Table (4) showed that the influence of location and storability on fruit texture $\left(\mathrm{g} / \mathrm{cm}^{2}\right)$ at $3 \mathrm{~mm}$ depth it is apparent that fruit texture was very lowering with development cold storage period. At the first season, New Valley dates texture was lowering from 92.00 to 71.67 after 360 days in cold storage according to [16], However, El-Wahat dates texture was decreased from 66.33 to 46.33 versus 80.33 to 60.33 in Siwa dates. Usually, it is obvious that New Valley dates exhibited higher texture values than El-Wahat dates or Siwa dates through all cold storage period. Considerable variations were pure among them. The same trend of findings was as well noted in the second season.

B- Chemical properties of dates:

Total Soluble Solids (T.S.S \%):

Data in Table (5) showed that the alteration in T.S.S\% as influenced by deferent location and storability on fruit (T.S.S \%) which greater with development in cold storage periods in any case of the utilized treatments according to [16]. On fruit T.S.S \%Recorded that on zero time for the first season $80.25 \%$ in New Valley after that Siwa dates $76.39 \%$ but El-Wahat dates recorded that $71.49 \%$. Generally, it is evident that New Valley dates exhibited higher T.S.S\% values than Siwa dates or El-Wahat dates during all cold storage duration. However, after 420 days on fruit T.S.S\% increased at cold storage duration recorded that first one New Valley $81.60 \%$ then Siwa dates $77.73 \%$ and last one El-Wahat dates $72.70 \%$. Significant differences were clear between them. The same trend of findings was also observed in the second season of the study. These above findings are in conforming to those obtained by [17] on "Sewy" and "Amry" dates Moreover, [18] on "Sewy" dates and [19] when achieved the influence of artificial ripening process on handling and storability of "Sewy" semi dry dates.

Total Acidity \%:

Data in Table (5) showed that the change in Total acidity $\%$ as influenced by deferent location and storability on fruit Total acidity \% which lowering with development in cold storage periods regardless of the utilized treatments on fruit Total acidity \%. On zero time for the first season recorded that 0.17 in New Valley after that Siwa dates 0.15 but El-Wahat dates recorded that 0.14 . Generally, it is evident that New Valley dates exhibited higher Total acidity \% values than Siwa dates or El-Wahat dates during all cold storage duration. However, after 420 days on fruit Total acidity \% increased at cold storage duration recorded that first one New Valley 0.58 then Siwa dates 0.58 and last one El-Wahat dates 0.57. Significant differences were clear between them. The same trend of findings was also observed in the second season of the study. These above findings are in conforming with those obtained by [17] on "Sewy" and "Amry" dates Moreover, [18] on "Sewy" dates and [16] when achieved the influence of artificial ripening process on handling and storability of "Sewy" semi dry dates.

Total Tannins (mg / 100g dry weight):

Data Table (5) showed that the alteration in Total tannins as affected by deferent location and storability on fruit Total tannins which lower with development in cold storage periods regardless of the utilize treatments according to [16]. On fruit Total tannins recorded that on zero time for the first season 0.38 in New Valley after that El-Wahat dates 0.29 but Siwa dates recorded that 0.26 . Generally, it is evident that New Valley dates exhibited higher Total tannins values than Siwa dates or El-Wahat dates during all cold storage duration. However, after 420 days on fruit Total tannins decreased at cold storage duration recorded that first one New Valley 0.24 then El-Wahat dates 0.19 and last one Siwa dates 0.16. Significant differences were clear between them. The same trend of findings was also observed in the second season of the study. These above findings are in conforming to those obtained by [14] on "Sewy" dates and [18] when achieved the influence of artificial ripening process on handling and storability of "Sewy" semi dry dates. 
Tarek M. El-Kafrawy et al., 2018. Evaluation of quality and storability of "Sewy" date palm cv. in different Production areas in Egypt. American-Eurasian Journal of Sustainable Agriculture. 12(1): 30-39. DOI: 10.22587/aejsa.2018.12.1.5

Table (5): Some chemical properties of "Sewy" dates for deferent location produced on cold stored, during two successive seasons.

\begin{tabular}{|c|c|c|c|c|c|c|c|c|}
\hline & \multicolumn{2}{|c|}{$\begin{array}{l}\text { T.S.S } \\
(\%)\end{array}$} & \multicolumn{2}{|c|}{$\begin{array}{l}\text { Acidity } \\
(\%)\end{array}$} & \multicolumn{2}{|c|}{$\begin{array}{c}\text { Tannins } \\
\text { (mg / 100g dry weight) }\end{array}$} \\
\hline & & & $1^{\mathrm{st}}$ & $2^{\text {nd }}$ & $1^{\text {st }}$ & $2^{\text {nd }}$ & $1^{\mathrm{st}}$ & $2^{\text {nd }}$ \\
\hline & & & season & season & season & season & season & season \\
\hline \multirow{3}{*}{ (A) : Location } & \multirow{3}{*}{\multicolumn{2}{|c|}{$\begin{array}{l}\left(A_{1}\right) \text { New Valley } \\
\left(A_{2}\right) \text { El-Wahat Bahria } \\
\text { (A3) Siwa }\end{array}$}} & 80.25 & 76.03 & 0.35 & 0.44 & 0.38 & 0.24 \\
\hline & & & 71.49 & 73.95 & 0.36 & 0.44 & 0.29 & 0.21 \\
\hline & & & 76.39 & 74.55 & 0.38 & 0.47 & 0.26 & 0.32 \\
\hline \multicolumn{3}{|c|}{ L.S.D. $(\mathrm{A})=$} & 0.61 & 0.49 & 0.03 & 0.02 & 0.02 & 0.02 \\
\hline \multicolumn{3}{|c|}{$\left(\mathrm{B}_{1}\right) 0$ day } & 74.88 & 73.71 & 0.15 & 0.28 & 0.42 & 0.36 \\
\hline \multicolumn{3}{|c|}{$\left(\mathrm{B}_{2}\right) 60$ days } & 75.18 & 74.00 & 0.18 & 0.38 & 0.40 & 0.34 \\
\hline \multicolumn{3}{|c|}{$\left(B_{3}\right) 120$ days } & 75.48 & 74.26 & 0.25 & 0.42 & 0.35 & 0.32 \\
\hline \multirow{7}{*}{$\begin{array}{l}\text { (B) : Storage } \\
\text { Date }\end{array}$} & \multicolumn{2}{|c|}{$\left(\mathrm{B}_{4}\right) 180$ days } & 75.82 & 74.63 & 0.33 & 0.45 & 0.31 & 0.28 \\
\hline & \multirow{2}{*}{\multicolumn{2}{|c|}{$\begin{array}{l}\left(\mathrm{B}_{5}\right) 240 \text { days } \\
\left(\mathrm{B}_{6}\right) 300 \text { days }\end{array}$}} & 76.17 & 75.01 & 0.41 & 0.47 & 0.29 & 0.25 \\
\hline & & & 76.53 & 75.36 & 0.46 & 0.51 & 0.27 & 0.21 \\
\hline & \multicolumn{2}{|c|}{$\left(\mathrm{B}_{7}\right) 360$ days } & 76.92 & 75.68 & 0.51 & 0.52 & 0.23 & 0.18 \\
\hline & \multicolumn{2}{|c|}{ (B $\mathrm{B}_{8} 420$ days } & 77.34 & 76.09 & 0.58 & 0.54 & 0.20 & 0.14 \\
\hline & \multicolumn{2}{|c|}{ S.D. $(B)=$} & 1.00 & 0.81 & 0.04 & 0.04 & 0.03 & 0.03 \\
\hline & \multirow[t]{8}{*}{$\mathrm{A}_{1}$} & $\mathrm{~B}_{1}$ & 79.07 & 72.83 & 0.17 & 0.26 & 0.52 & 0.34 \\
\hline \multirow{24}{*}{$\begin{array}{l}(\mathrm{AXB}): \\
\text { Interaction }\end{array}$} & & $\mathrm{B}_{2}$ & 79.47 & 73.23 & 0.19 & 0.37 & 0.49 & 0.33 \\
\hline & & $\mathrm{B}_{3}$ & 79.67 & 73.33 & 0.22 & 0.42 & 0.43 & 0.31 \\
\hline & & $\mathrm{B}_{4}$ & 79.90 & 73.67 & 0.31 & 0.45 & 0.38 & 0.26 \\
\hline & & $\mathrm{B}_{5}$ & 80.37 & 74.07 & 0.38 & 0.47 & 0.36 & 0.23 \\
\hline & & $\mathrm{B}_{6}$ & 80.70 & 74.43 & 0.43 & 0.51 & 0.32 & 0.18 \\
\hline & & $\mathrm{B}_{7}$ & 81.20 & 74.80 & 0.49 & 0.51 & 0.28 & 0.16 \\
\hline & & $\mathrm{B}_{8}$ & 81.60 & 75.20 & 0.58 & 0.51 & 0.24 & 0.12 \\
\hline & \multirow[t]{8}{*}{$\mathrm{A}_{2}$} & $\mathrm{~B}_{1}$ & 70.43 & 73.33 & 0.14 & 0.29 & 0.40 & 0.31 \\
\hline & & $\mathrm{B}_{2}$ & 70.67 & 73.57 & 0.15 & 0.36 & 0.39 & 0.29 \\
\hline & & $\mathrm{B}_{3}$ & 70.97 & 73.93 & 0.26 & 0.41 & 0.32 & 0.27 \\
\hline & & $\mathrm{B}_{4}$ & 71.37 & 74.37 & 0.34 & 0.45 & 0.29 & 0.23 \\
\hline & & $\mathrm{B}_{5}$ & 71.53 & 74.77 & 0.42 & 0.46 & 0.26 & 0.20 \\
\hline & & $\mathrm{B}_{6}$ & 71.97 & 75.13 & 0.47 & 0.50 & 0.25 & 0.16 \\
\hline & & $\mathrm{B}_{7}$ & 72.27 & 75.40 & 0.51 & 0.50 & 0.22 & 0.14 \\
\hline & & $\mathrm{B}_{8}$ & 72.70 & 75.87 & 0.57 & 0.51 & 0.19 & 0.12 \\
\hline & \multirow[t]{8}{*}{$\mathrm{A}_{3}$} & $\mathrm{~B}_{1}$ & 75.13 & 74.97 & 0.15 & 0.29 & 0.33 & 0.42 \\
\hline & & $\mathrm{B}_{2}$ & 75.40 & 75.20 & 0.19 & 0.41 & 0.30 & 0.40 \\
\hline & & $\mathrm{B}_{3}$ & 75.80 & 75.50 & 0.28 & 0.43 & 0.30 & 0.38 \\
\hline & & $\mathrm{B}_{4}$ & 76.20 & 75.87 & 0.35 & 0.45 & 0.26 & 0.33 \\
\hline & & $\mathrm{B}_{5}$ & 76.60 & 76.20 & 0.45 & 0.48 & 0.25 & 0.31 \\
\hline & & $\mathrm{B}_{6}$ & 76.93 & 76.50 & 0.48 & 0.52 & 0.24 & 0.28 \\
\hline & & $\mathrm{B}_{7}$ & 77.30 & 76.83 & 0.54 & 0.55 & 0.20 & 0.23 \\
\hline & & $\mathrm{B}_{8}$ & 77.73 & 77.20 & 0.58 & 0.59 & 0.16 & 0.19 \\
\hline & \multicolumn{2}{|c|}{ L.S.D. $(\mathrm{AXB})=$} & 1.73 & 1.40 & 0.08 & 0.06 & 0.05 & 0.05 \\
\hline
\end{tabular}


Tarek M. El-Kafrawy et al., 2018. Evaluation of quality and storability of "Sewy" date palm cv. in different Production areas in Egypt. American-Eurasian Journal of Sustainable Agriculture. 12(1): 30-39. DOI: 10.22587/aejsa.2018.12.1.5

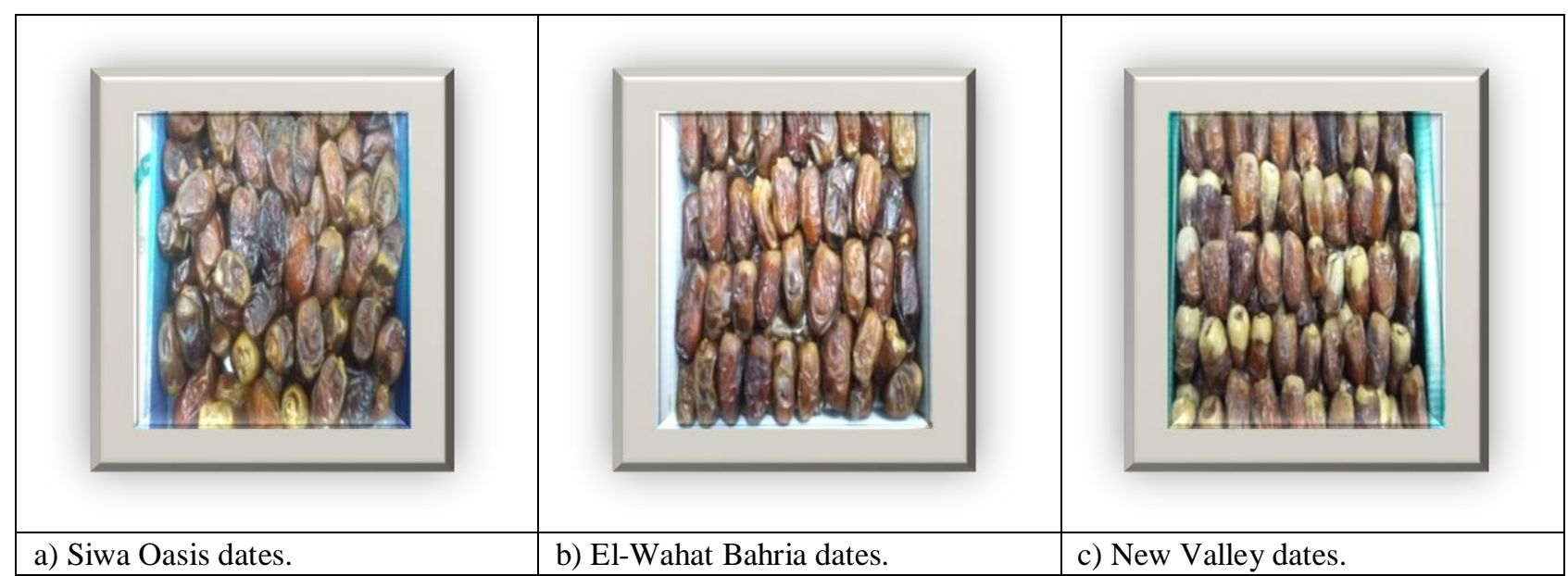

Fig. 1: Pictures of date fruits "Sewy" from the three different production areas: a) Siwa Oasis dates, b) El-Wahat Bahria dates and c) New Valley dates.

\section{CONCLUSION}

The study showed that there is a clear difference in the quality of through physical properties, chemical, and storability traits under study, for the first experiment the quality attributes recorded for El-Wahat Bahria increased of physical properties. Date of Second experiment showed that New Valley is best areas for good storability of list. Also, it characterized by good taste, good appearance and color of the fruits of the accepted.

\section{REFERENCES}

[1] FAO, (2009). Food and Agriculture Organization of the United Nations. http://faostat.fao.org/site.

[2] FAOSTAT, (2014). Food and Agriculture Organization Agro-Statistics Database. FAO: Roma.

[3] El-Habbab, M.S. and H.S. Ghazzawy (2016). Wholesale and Retail Price Integration for Date Palm in Saudi Arabia. Indian Journal of Research, ISSN - 2250-1991, Volume 5, Number 9, pp. 174-178.

[4] AOAD - Khartoum (2015a). ARAB Agricultural Statistics Yearbook, Part 3 plant production Vol. No. (35) Page 41-Table 72.

[5] AOAD - Khartoum (2015b). ARAB Agricultural Statistics Yearbook, Part 7 Exports Vol. No. (34) Page 231-Table 240.

[6] Albert, D.W. and R.H. Hilgman (1933). Fruit growth and temperature relationship in the date palm. Proc. Amer. Soc. Hort. Sci., 30: 225-228.

[7] Hussein, F.; M.S. El-Katany and Y.A. Wally (1979). Date Palm Growing and Date Production in the Arab and Islamic World. Ain Shams press, Egypt. (In Arabic).

[8] Ghazzawy, H.S., M.M. Khamis, M.M. Sharf and A. El-Bana (2010). Effect of pollen grain sources on yield and quality on Zaghloul and Sewy cvs. Journal of Agriculture Research. Vol. 22 No. (12).

[9] Ibrahim, A.M. and Hajaj, M.N. (1993). Tamr palm, cultivation and production. pp. 650. Dar Al-Maaref, Alexandria, Egypt. (In Arabic).

[10] Amer, W.M 2000. Date palm, (Phoenix dactylifera L). Cultivars in Egypt. El-Minia Science Bulletin, Vol. 13:(1) $1-15$.

[11] Azadi, H., G.H. Hosseininia and M. Azadi (2006)."North-South GM crops transfers and organic farming: The question of food security in South countries". Paper presented at the International Conference of Economics of Poverty, Environment and Natural Resource Use, 17-19 May 2006, Wageningen, The Netherlands.

[12] Eisa, H., M.H. Khoshtaghaza, A. Mostaan and A. Banakar (2012). Effect of storage duration on some physical properties of date palm (cv. Samaran). Journal of the Saudi Society of Agricultural Sciences.

[13] A.O.A.C. (2000). Association of official Agricultural chemistry. Methods of analysis (15 $5^{\text {th }}$ ed). Washington, DC, USA.

[14] Yeshajahu, P.Z. and Clifton, E.M. (1977). Food Analysis, Theory and Practice. Avi publishing Co., Westport, U.S.A.

[15] Snedecor, G.W. and W.G. Cochran (1980). Statistical Methods, $7^{\text {th }}$ ed. Iowa State Univ. Press, Ames, Iowa, USA. 
Tarek M. El-Kafrawy et al., 2018. Evaluation of quality and storability of "Sewy" date palm cv. in different Production areas in Egypt. American-Eurasian Journal of Sustainable Agriculture. 12(1): 30-39. DOI: 10.22587/aejsa.2018.12.1.5

[16] El-Kafrawy, T.M. (2008). Effect of some environmentally safe pre and post-harvest treatments on yield and fruit quality of date palm Thesis Submitted in Partial Fulfillment of the Requirement for the of Ph.D. of Environmental Studies \& Research, Ain Shams University, Egypt.

[17] Salah El-Din, I.K. (1967). Factors influencing the quality of dehydrated dates. M.Sc. Thesis of Faculty of Agriculture, Cairo University, Egypt.

[18] El-Hammady, A.M.; A.S. Montasser, N. Abdel-Hamid, M. Nageib and Elham Zinhoum (2003). Ripening of "Sewy" date fruits as affected with post-harvest application of ethephon or calcium carbide. Journal of Environmental Science Vol. 5 No. 3, December, 2003 (34), Egypt.

[19] El-Hadidy, G.A.E. (2004). Safe environmental treatments for handling semi dry date. M.Sc. Thesis, Fac. Agric., Ain Shams University, Egypt.

[20] Jimenez L; L. Ferrer and ML. Paniego (1989). J. Food Eng. P. 119-128. 